\title{
An improved infrared carbon monoxide analyser for routine measurements aboard commercial Airbus aircraft: technical validation and first scientific results of the MOZAIC III programme
}

\author{
P. Nedelec ${ }^{1}$, J.-P. Cammas ${ }^{1}$, V. Thouret ${ }^{1}$, G. Athier ${ }^{1}$, J.-M. Cousin ${ }^{1}$, C. Legrand ${ }^{2}$, C. Abonnel ${ }^{3}$, F. Lecoeur ${ }^{4}$, G. Cayez $^{5}$, \\ and C. Marizy ${ }^{6}$ \\ ${ }^{1}$ Laboratoire d'Aérologie, CNRS, Observatoire Midi-Pyrénées, UMR 5560, 14 Avenue Edouard Belin, 31400 Toulouse, \\ France \\ ${ }^{2}$ Air C.O.M., Avenue Tsukuba, 14200 Herouville Saint Clair, France \\ ${ }^{3}$ Météo-France, Centre d'Aviation Météorologique, Aérodrome, 91228 Brétigny-sur-Orge, France \\ ${ }^{4}$ Météo-France, Direction des Systèmes d'Observation de la Météorologie, 7 Rue Teisserenc-de-Bort, BP 202, 78195 \\ Trappes, France \\ ${ }^{5}$ Météo-France, Direction Interrégionnale Nord-Est, BP 124 Parc d'Innovation, Boulevard Gonthier d'Andernach, 67403 \\ Illkirch Cedex, France \\ ${ }^{6}$ Airbus France, 316 Route de Bayonne, 31300 Toulouse, France
}

Received: 14 April 2003 - Published in Atmos. Chem. Phys. Discuss.: 25 July 2003

Revised: 25 September 2003 - Accepted: 25 September 2003 - Published: 29 September 2003

\begin{abstract}
The European-funded MOZAIC programme (Measurements of ozone and water vapour by Airbus inservice aircraft) has been operational since 1994 aboard 5 commercial Airbus A340. It has gathered ozone and water vapour data between the ground and an altitude of $12 \mathrm{~km}$ from more than 20000 long-range flights. A new infrared carbon monoxide analyser has been developed for installation on the MOZAIC equipped aircraft. Improvements in the basic characteristics of a commercial $\mathrm{CO}$ analysers have achieved performance suitable for routine aircraft measurements : $\pm 5 \mathrm{ppbv}, \pm 5 \%$ precision for a $30 \mathrm{~s}$ response time. The first year of operation on board 4 aircraft with more than 900 flights has proven the reliability and the usefulness of this $\mathrm{CO}$ analyser. The first scientific results are presented here, including UTLS exchange events and pollution within the boundary layer.
\end{abstract}

\section{Introduction}

Carbon monoxide (CO) is a key trace gas within tropospheric photochemistry. The reaction of $\mathrm{CO}$ with the hydroxyl radical $(\mathrm{OH})$ provides a constraint on the concentration of $\mathrm{OH}$ in the unpolluted atmosphere (Logan et al., 1981), and thus on the oxidizing capacity in the troposphere. Changes in $\mathrm{OH}$ oxidation due to changes in $\mathrm{CO}$ concentrations could perturb

Correspondence to: P. Nedelec

(nedp@aero.obs-mip.fr) the concentration of greenhouse gases such as $\mathrm{CH}_{4}$ and $\mathrm{O}_{3}$ (Thompson and Cicerone, 1986). Thus a better understanding of the atmospheric distribution of $\mathrm{CO}$ is important for the assessment of climate change.

Tropospheric CO concentrations have been measured globally at monitoring stations in the planetary boundary layer (Novelli et al., 1998 and references therein). Whilst aircraft, satellites and balloons are used for measurements of global $\mathrm{CO}$, these data are relatively sparse compared to those measurements made within the boundary layer. Vertical distributions of $\mathrm{CO}$ over continental regions were recently gathered by aircraft during several regional campaigns - see Emmons et al. (2000) for list, details and data composites maps issued from these measurements. During the STRATOZIII mission (Marenco et al., 1989), CO measurements were performed aboard an instrumented Caravelle aircraft between $70^{\circ} \mathrm{N}-60^{\circ} \mathrm{S}$. More recently, a Japanese passenger aircraft programme performed measurements of $\mathrm{CO}$ in the upper troposphere through automatic flask sampling system (Matsueda et al., 1998 and references therein) between $30^{\circ} \mathrm{N}$ and $30^{\circ} \mathrm{S}$ at approximately the longitude of Japan. A worldwide picture of $\mathrm{CO}$ distribution patterns in the middle troposphere was clearly captured by the MAPS experiment (Reichle et al., 1986, 1990, 1999) in 1981, 1984 and 1994. Since the beginning of 2000, the MOPITT instrument onboard the TERRA satellite has delivered a global picture of CO (Edwards et al. 2003). 
Despite the existing CO measurements available for different regions, seasons, and resolutions, more frequent in-situ measurements are still necessary for a better understanding of the global cycle of $\mathrm{CO}$ and to help improve our knowledge of other key constituents such as ozone and $\mathrm{OH}$.

Therefore, the MOZAIC programme (Marenco et al., 1998) was extended to perform measurements of CO onboard the 5 aircraft already equipped with ozone and water vapour sensors. Since December 2001, the five MOZAIC aircraft have been successively equipped and now provide automatic $\mathrm{CO}$ measurements along the main routes operated by Lufthansa, Air France and Austrian airlines with 3,1 , and 1 aircraft respectively (see web site for details http://www.aero.obs-mip.fr/mozaic/). In the perspective of understanding the ozone budget, having the $\mathrm{CO}$ measurements along with ozone is of particular interest. $\mathrm{CO}$ has both natural and anthropogenic sources. Naturally produced CO results primarily from the oxidation of methane and other hydrocarbons (notably isoprene). Anthropogenically produced $\mathrm{CO}$ results mainly from the combustion of fossil fuels dominantly in the northern hemisphere and from biomass burning in the tropics. Its chemical lifetime varies from about one month in the tropics to about a year in the wintertime polarregions. Therefore $\mathrm{CO}$ can be transported long distances from its sources, resulting in mixing ratios that vary widely over the planet. Moreover, $\mathrm{CO}$ is one of the main ozone precursors and as it is emitted directly by human activities, this makes it a good tracer species for anthropogenic emissions thus helping to differentiate the peaks of ozone concentration (pollution or stratospheric intrusions).

The goals of this paper are two fold. Firstly, we present the measurements technique, the constraints imposed by automatic use onboard a passenger aircraft, the instrument validation and the quality testing. We then describe some scientific issues that have arisen from the first flights which have given new perspectives on regional and global $\mathrm{CO}, \mathrm{O}_{3}$ and $\mathrm{H}_{2} \mathrm{O}$ distributions.

\section{The MOZAIC CO analyser}

\subsection{Choice of the analytical principle}

The MOZAIC programme is a long term programme involving automatic systems onboard five commercial Airbus A340 aircraft (Marenco et al., 1998). Since 1994, it automatically collected measurements of ozone, water vapour and standard meteorological parameters (Pressure, Temperature, wind speed and direction) during more than 20000 flights, which represents about 145000 hours of flight. The instrumental environment in a commercial aircraft is harsh due to large temperature and pressure variations and strong vibrations mainly during take-off, landing, but also sometimes during cruise. In addition, the maintenance of the MOZAIC systems is limited by the rare and short periods of availability of the aircraft at the airlines home bases. Due to practical constraints, systems replacement due to failure can only be achieved every five to six weeks. For these reasons, the choice of the $\mathrm{CO}$ analyser has to be a compromise between measurement performance (response time, sensitivity), weight and long-term reliability without the use of laboratory tests for calibration. Several techniques have been used for measuring carbon monoxide onboard aircraft : grab samples followed by laboratory gas chromatographic analysis (Matsueda et al., 1998 and 1999), in-situ gas chromatography with FID or mercury vapour detectors (Marenco et al., 1989, Hoel et al., 1987), tunable diode laser (Sachse et al., 1987, 1991) or more recently resonance fluorescence instruments (Volz et al., 1985, Gerbig et al., 1996, Takegawa et al., 2001). Although these methods are accurate and in the case of the last two offer fast response time, their use for long-term routine operation aboard aircraft remains difficult, as it is limited by the instruments weight and by the use of compressed gas for in-situ calibration. For the MOZAIC programme, where systems have to be operated continuously for months without maintenance, another method has been chosen. Although the IR gas filter correlation (GFC) is less sensitive than the other principles listed above, its simplicity, stability and recent improvements has made this choice realistic. It has been used extensively by different groups involved in long term ground based measurements (Dickerson et al., 1987, Parrish et al., 1994) and in intercomparison campaigns with tunable diode laser (Fried et al., 1991). One of the important advantages of this method is the long term stability of the calibration factor, which obviates the need for an in-situ calibration using compressed gas cylinders. This reduces the weight of the equipment, increases the time between services and leads to easier certification for commercial aircraft.

\subsection{Principle and improvement of the sensor performance}

The MOZAIC CO analyser is an improved version of a commercial Model 48CTL from Thermo Environmental Instruments, based on the Gas Filter Correlation principle of infrared absorption by the $4.67 \mu \mathrm{m}$ fundamental vibrationrotation band of CO. Radiation from an infrared source is chopped and passes through a gas filter which alternates between $\mathrm{CO}$ and $\mathrm{N}_{2}$ via the rotation of the filter wheel. The radiation then passes through a narrow band pass filter and a multiple optical pass sample cell where absorption by the sample gas occurs. The IR radiation exits the sample cell and falls on a PbSe solid state IR detector. Other gases do not cause modulation of the detector signal since they absorb the reference and measure beams equally. Thus, the Gas Filter Correlation System responds specifically to CO. The Model 48CTL is qualified by U.S. EPA designated Method (EQSA0486-060). The accuracy specification of the commercial instrument is $10 \mathrm{ppbv} \mathrm{CO}$ for $300 \mathrm{~s}$ integration time.

Several major modifications have been added by the authors in order to improve the Model 48CTL instrument 


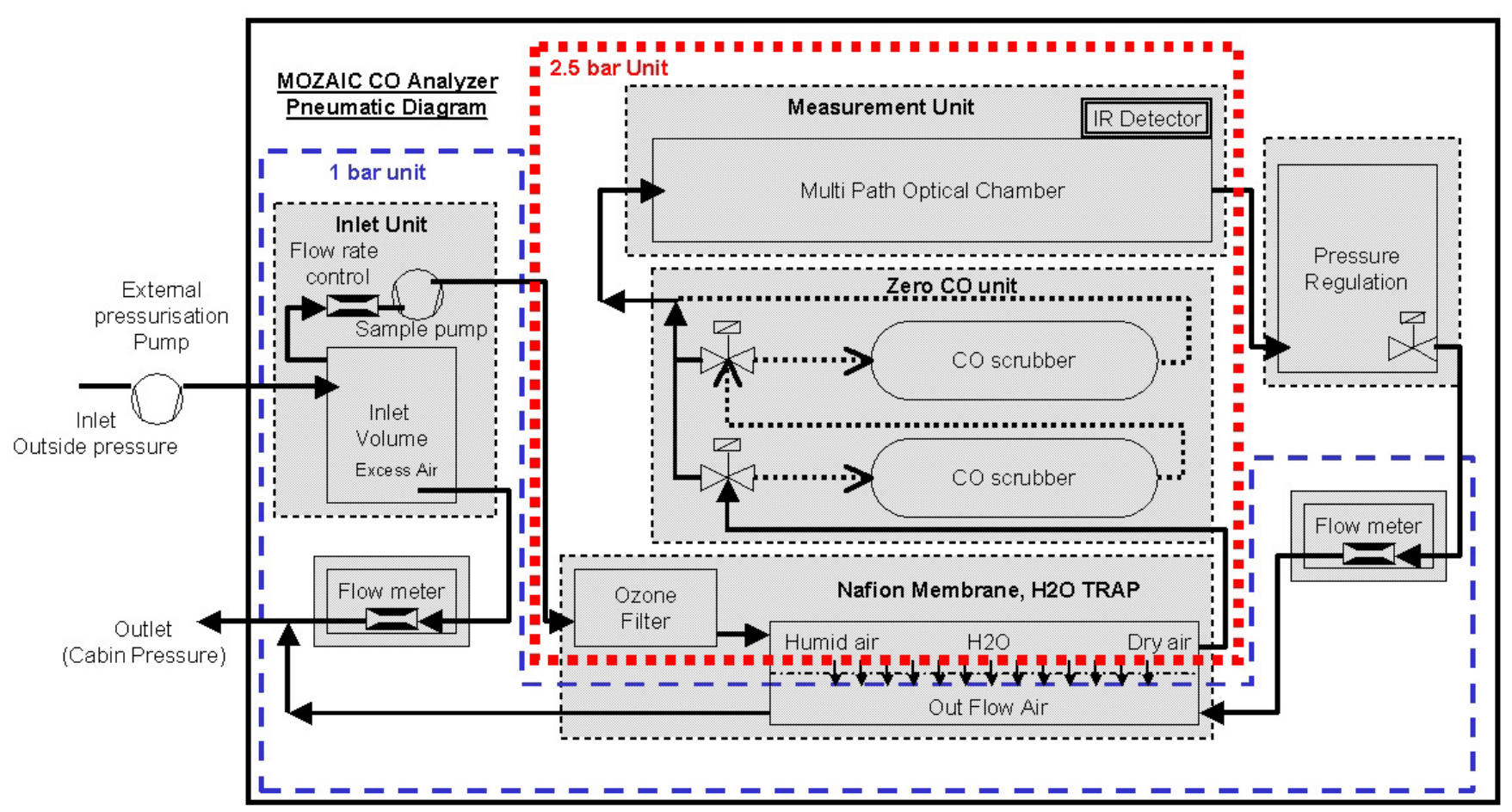

Fig. 1. MOZAIC CO analyser schematic diagram. Air from outside is pressurised to aircraft cabin pressure at the inlet volume, then passes through ozone and water vapour traps. For zeroing, the sampled air can be passed via one or two CO scrubbers before entering the pressurised optical chamber where IR absorption occurs.

characteristics (schematic diagram displayed on Fig. 1). The first one is to make periodical accurate zero measurements. This is necessary because of the zero drift of the instrument due to internal temperature fluctuations. A SOFNOCAT catalyst from Molecular Products Ltd. is used in a volume sufficient to remove $\mathrm{CO}$ by oxidising to $\mathrm{CO}_{2}$ more than $99 \%$ of the atmospheric CO. This catalyst is hydrophobic, so is not sensitive to water vapour variations in the air. The zero mode is applied for $40 \mathrm{~s}$ every $20 \mathrm{~min}$ and the zero level is linearly interpolated between two zeroes during data processing. During long term operation, a second catalyst element is periodically used in series to test the validity of the zeroing.

The second major modification is the use of a new $\mathrm{PbSe}$ IR detector (BxT2S series from Cal Sensors, Inc.) with a two stage thermoelectric cooler integrated to regulate its temperature down to $-30^{\circ} \mathrm{C}$. The lower temperature and the temperature regulation reduce significantly the signal-to-noise ratio. The low voltage signal from the IR detector requires special care to ground the different elements of the instrument.

The third major modification increases and maintains the pressure within the absorption cell to 2.5 bar. This higher pressure provides more $\mathrm{CO}$ molecules for IR absorption, hence increases the signal-to-noise ratio by a factor about of two, compared to a pressure of 1 bar.

\subsection{Laboratory tests}

As major modifications have been applied to the commercial analyser (Model 48CTL), extensive laboratory tests have been conducted to validate the MOZAIC CO analyser. The analysers are periodically calibrated in the laboratory using $\mathrm{CO}$ ppmv range concentrations in air from compressed cylinders with a NIST specification for $\mathrm{CO}$ concentration and a dilution system which use calibrated mass flow controllers from Bronkhorst High-Tech BV. The linearity has been checked between 0 and 1160 ppbv (Fig. 2) and is shown to be almost one (the $3 \mathrm{ppbv}$ offset is due to the precision of the measurement which is $\pm 5 \mathrm{ppbv}$ ). Several months of operation onboard the aircraft have not, up to the present, affected the calibration of the instruments, as all the instrument voltages and pressure are regulated and recorded.

High concentrations of water vapour in the troposphere are a major interference in atmospheric $\mathrm{CO}$ measurements at ppb levels (Dickerson et al., 1987), due to significant water vapour IR absorption. A Nafion membrane from Perma Pure, Inc. was installed to dry the air before the measurement, using the pressure difference between the pressurised stage and ambient pressure stages (Fig. 1). The water molecules from the pressurised air move through the Nafion membrane wall and evaporate into the lower pressure air. The interference of water vapour has been experimentally tested in laboratory, 


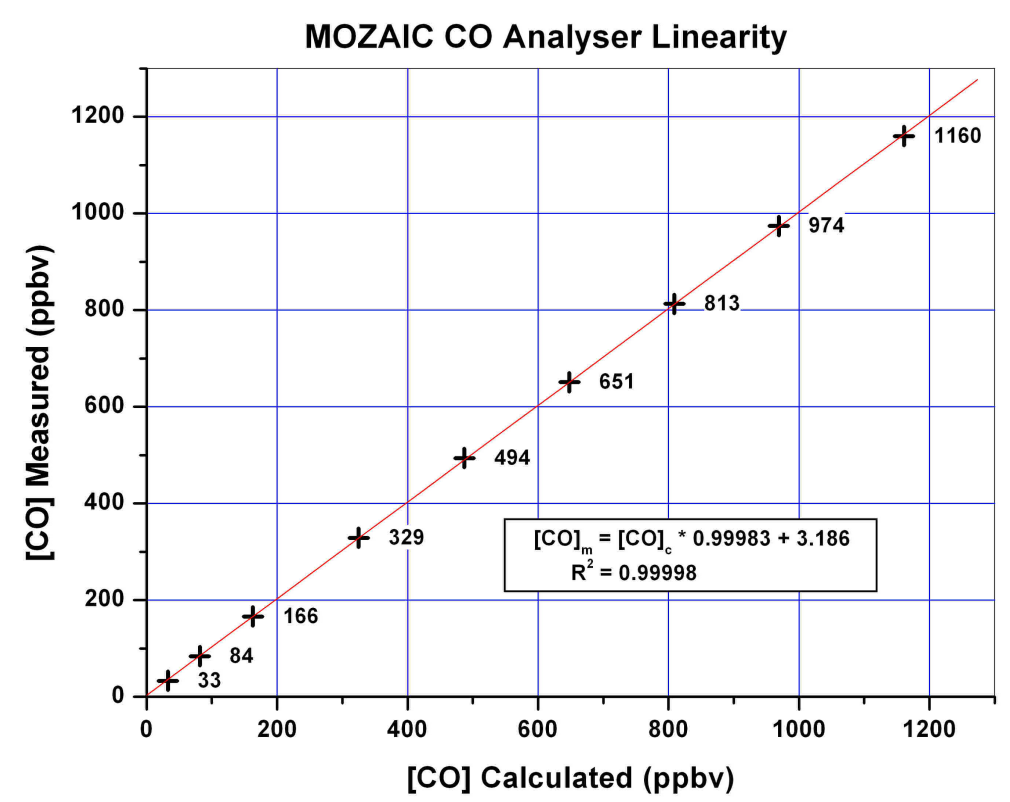

Fig. 2. MOZAIC CO analyser linearity in the current atmospheric CO ranges, using NIST compressed cylinders ppmv range CO in air. The dilution system was using Mass Flow controllers from Bronkhorst Hi-Tec B.V. The linearity of the instrument is almost 1 , the -3.16 ppbv offset coming from the measurement precision $( \pm 5 \mathrm{ppbv})$.

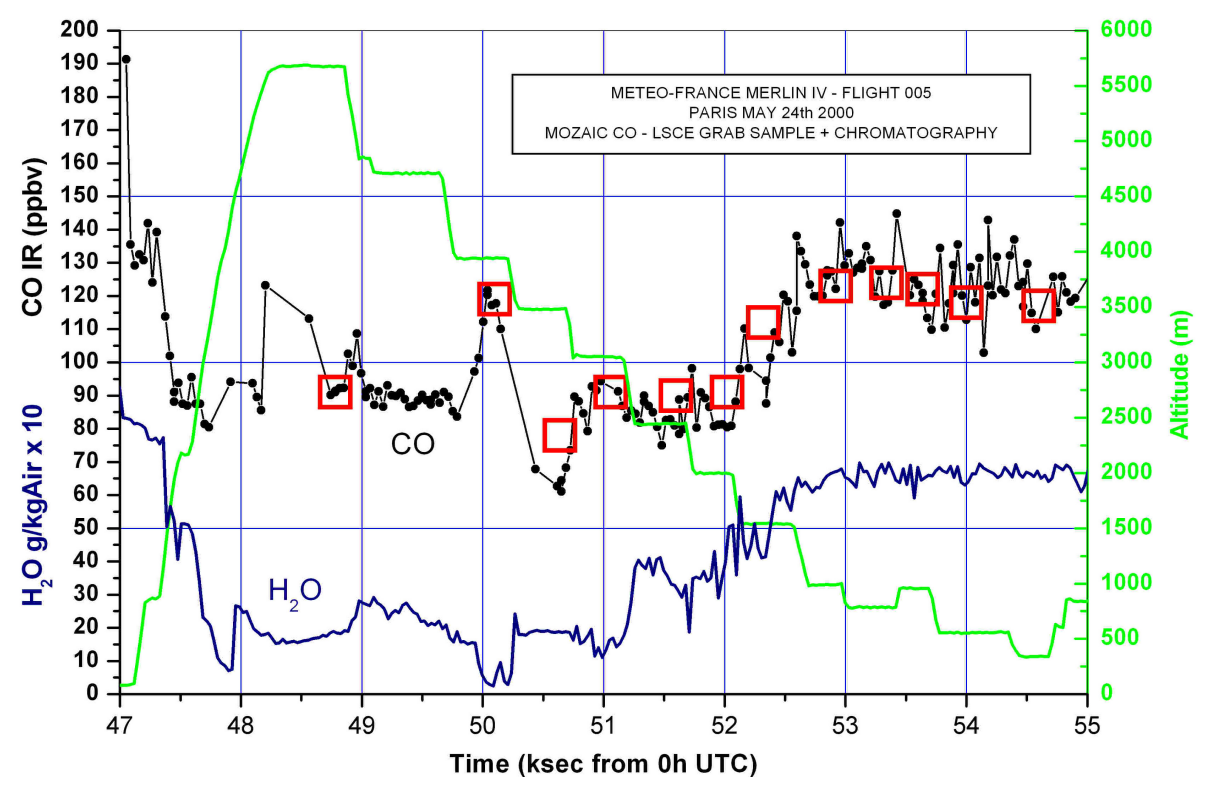

Fig. 3. Aircraft test flight realised on 24 May 2000, on Météo-France Merlin IV up to $5.7 \mathrm{~km}$ altitude (green line). MOZAIC CO analyser in-situ measurements (black line and circles) are plotted with post-flight laboratory GC analysis of 12 grab samples (red squares). Agreement between both is within the uncertainty of the two methods. In particular, the water vapour variations between $0.5 \mathrm{and} 8 \mathrm{~g} / \mathrm{kg}$ air do not show any influence.

at the Centre d'Aviation Météorologique facilities (MétéoFrance). If the Nafion drier is not used, the artefact measured concentration is about +6 ppbv $\mathrm{CO}$ per $\mathrm{hPa} \mathrm{H}_{2} \mathrm{O}$. This can compared to the 12 ppbv $\mathrm{CO}$ per $\mathrm{hPa} \mathrm{H}_{2} \mathrm{O}$ found by other authors (Fried et al., 1991). This difference may be explained by the 2.5 bar pressure used in this instrument but not by 


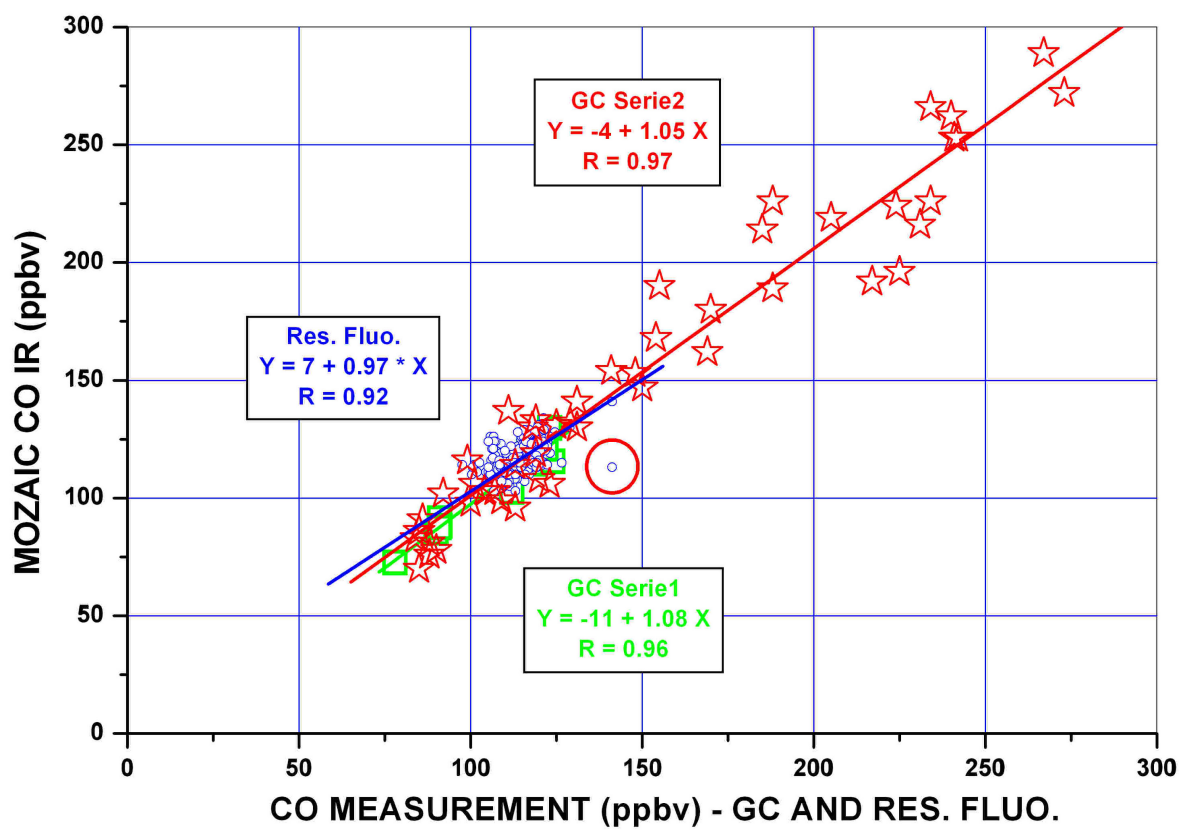

Fig. 4. Regression of the overlapping CO measurements during five intercomparison flights, with MOZAIC CO measurements on the vertical scale. Blue points are the measurements made by the Dornier 128 Aerolaser UV resonance fluorescence instrument. The one circled in red represents a plume not captured by MOZAIC CO analyser. Green squares are the flask samples GC analysis by LSCE for the Météo-France Merlin IV flight. Red stars are the GC analysis by LSCE for the DLR Falcon 20 flights. Linear regressions are drawn in corresponding colours, with their calculation.

Fried et al. The artefact is apparent in both the sample and zero modes, as the zero catalyst is hydrophobic. This could result in no net interference, but water vapour concentrations can change extremely rapidly in the atmosphere, especially when sampled by high speed aircraft, so it is critical to remove this interference directly. Laboratory tests made with the Nafion membrane installed show that the artefact CO signal from water vapour is negligible.

Ozone can reach high concentrations in the low stratosphere (ppmv level) and can potentially act as an interference with transition bands of ozone overlapping the CO fundamental band (Dickerson et al., 1987). A commercial ozone trap made of $\mathrm{MnO}_{2}$ has been added before the measuring cell (Fig. 1) and ozone interference has been checked in the laboratory up to $1 \mathrm{ppmv}$ ozone and has been found to be non existent. The $\mathrm{MnO}_{2}$ filter has also been tested in laboratory to ensure that it has no interference (positive or negative) on the $\mathrm{CO}$ measurement.

\subsection{Instrument specifications}

As the MOZAIC systems including the $\mathrm{CO}$ analysers are installed on commercial Airbus A340 aircraft, they have been certified according to the European Joint Aviation Authorities (JAA) requirements. This qualification has been achieved by EADS in Toulouse during the MOZAIC III programme. It includes structural modifications and shock ab- sorber installation, EMI and vibration tests which were performed at EADS facilities, smoke and overheating detection and the use of aeronautic electrical components. The final weight of the MOZAIC CO analyser is $29 \mathrm{~kg}$ with 170 Watt power consumption. For operation at high altitudes up to $12.4 \mathrm{~km}$ (180 mbar), an external pressurisation pump is used (KNF Neuberger, Inc., Model N035, $11.2 \mathrm{~kg}$ ). Before the final Airbus validation of this new $\mathrm{CO}$ analyser, five test flights have been performed in 1999 and 2000 using the Airbus Industrie A340 MSN001 prototype aircraft. This has proven the operation of the analyser in flight conditions, at high altitudes up to the A340 maximum altitude of 41000 feet $(12.4 \mathrm{~km})$.

These flights have shown the instrument stability for measuring low concentrations of $\mathrm{CO}$, down to a mean of $40 \mathrm{ppbv}$ $\mathrm{CO}$ concentrations observed in the stratosphere. The specifications achieved for $30 \mathrm{~s}$ integration time (response time of the instrument to flush the absorption cell) are the following: measurement precision $\pm 5 \mathrm{ppbv} \mathrm{CO}$ (signal noise), $\pm 5 \%$ (calibration), minimum detectable $10 \mathrm{ppbv} \mathrm{CO}$. As the Airbus A340 aircraft maximum cruise speed is nearly $250 \mathrm{~m} / \mathrm{s}$, this analyser samples at a horizontal resolution of about $7 \mathrm{~km}$, and a vertical resolution of about $300 \mathrm{~m}$ during ascents and descents. The $\mathrm{CO}$ analysers are now installed on the five MOZAIC equipped Airbus A340, operated free of charge by Lufthansa (3), Air France and Austrian Airlines. 


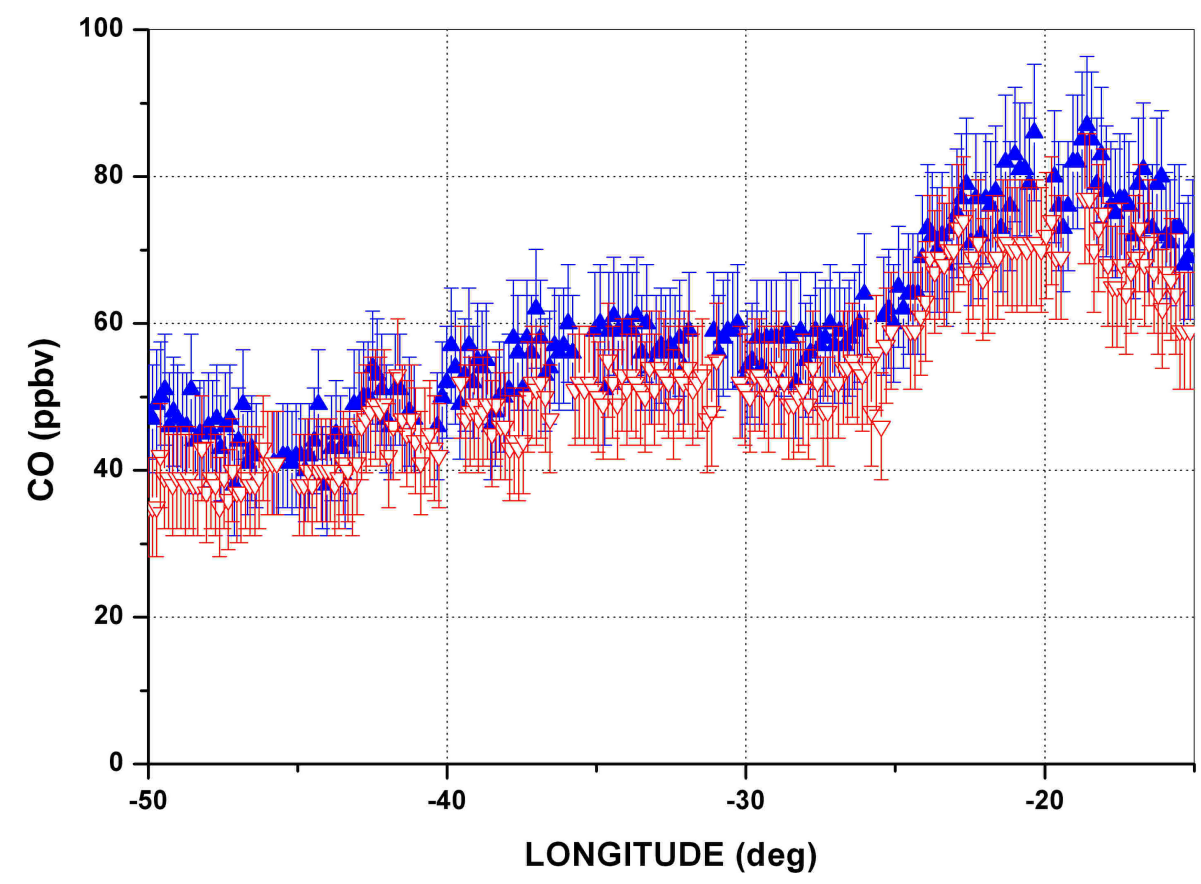

Fig. 5. Two MOZAIC aircraft during flights from Chicago to Munich and from Detroit to Frankfurt, on 10 October 2002 . The aircraft coincidence is during 2 hours and 20 min over the Atlantic ocean between $50^{\circ} \mathrm{N}, 50^{\circ} \mathrm{W}$ and $53^{\circ} \mathrm{N}, 15^{\circ} \mathrm{W}$. The two Lufthansa aircraft are flying at 37000 feet $(11250 \mathrm{~m})$, with a lag time of only $10 \mathrm{~min}$. CO measurements are shown with $30 \mathrm{~s}$ mean values, with their uncertainty bars $( \pm 5 \mathrm{ppbv}, \pm 5 \%)$, in red for the first aircraft, blue for the second one $10 \mathrm{~min}$ later.

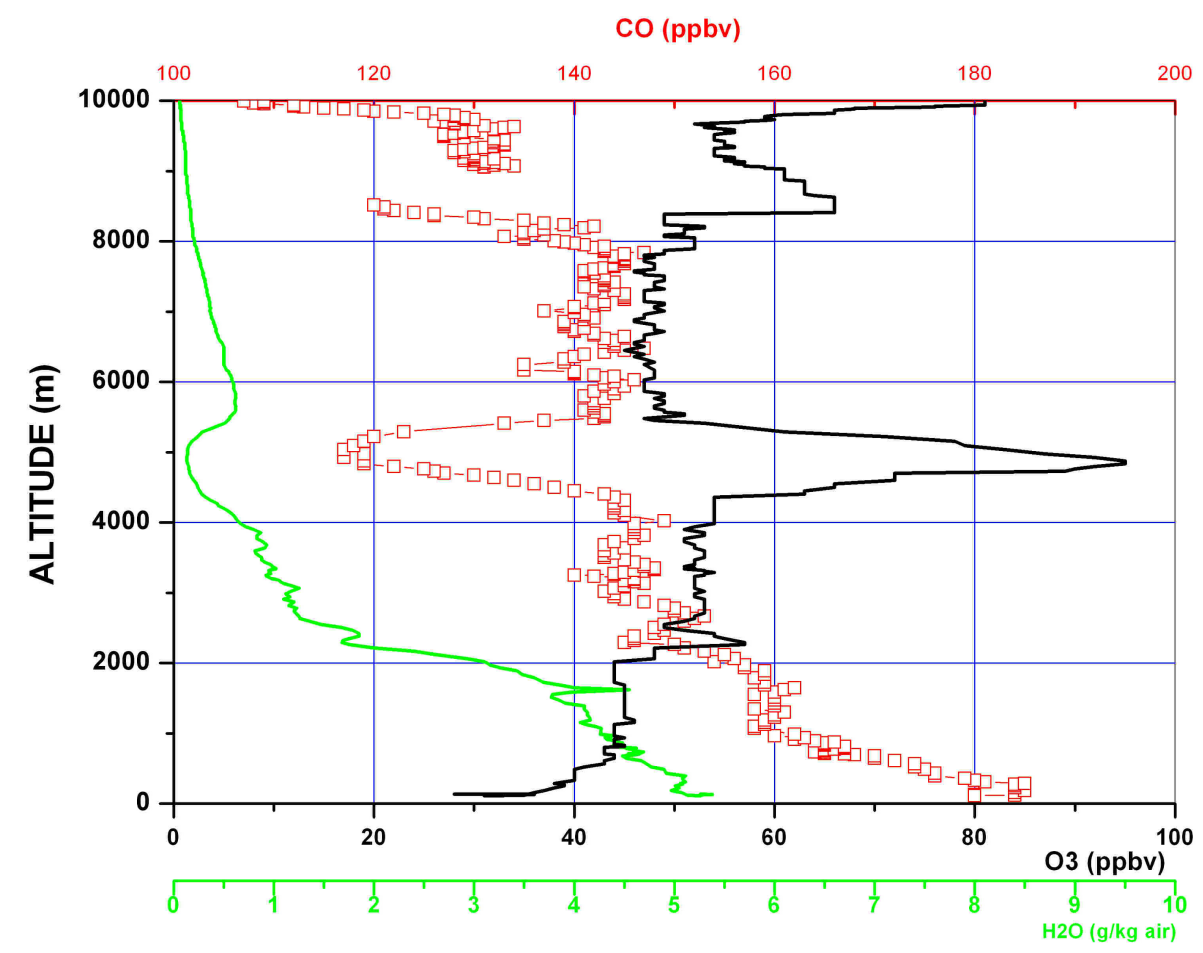

Fig. 6. Vertical profile over Frankfurt (Germany) on 10 February 2002 from 12:34 UTC to 13:01 UTC. Shown are the mixing ratio of ozone (ppbv, black solid line), carbon monoxide (ppbv, red square line) and water vapour ( $\mathrm{g} / \mathrm{kg}$, green line) versus altitude (m). 


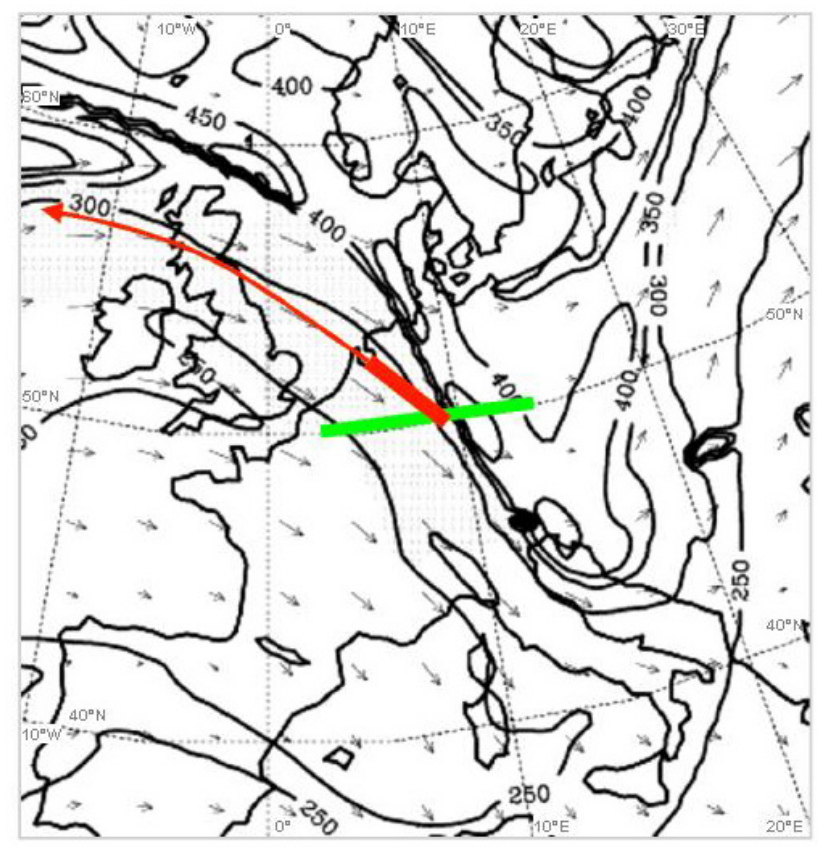

Fig. 7. Pressure (contours every $50 \mathrm{hPa}$ ) and wind (vectors, shading for wind speeds in excess of $50 \mathrm{~ms}^{-1}$ ) at the tropopause (defined as 1.5 pvu surface) on 10 February 2002, 12:00 UTC from ECMWF analyses. Horizontal line of the vertical cross-section shown on Fig. 9 is displayed in green about $50^{\circ} \mathrm{N}$. Flight track is displayed in red, larger for the ascending part of the flight.

\subsection{CO measurements in-flight comparisons}

\subsubsection{Dedicated research aircraft experiments}

The MOZAIC CO analyser has also been flown and tested on a variety of European research aircraft: Météo-France Merlin IV for test flights in 2000, CNRS/INSU Dassault Mystère 20 for the $\mathrm{PICO}_{3}$ campaign in October 2000, CNRS/INSU Fokker 27 "ARAT" during the ESCOMPTE campaign in July 2001 and the DLR Falcon 20 during CAATER2 in October 2002 (Co-ordinated Access to Aircraft for Trans-national Environmental Research). These comparison flights afforded the opportunity to compare the MOZAIC instrument with two other measurement methods.

The intercomparison flight presented in Fig. 3 was performed on May 24th 2000, aboard the Météo- France Merlin IV. The objective of this flight above the Orléans forest (south of Paris, France) was to compare the continuous CO measurements made by the MOZAIC analyser with whole air samples which were analysed post-flight by LSCE (Laboratoire des Sciences du Climat et de l'Environnement, Paris, France) for the RAMCES programme (Gros et al., 1998). The LSCE routine CO analysis is made using a Trace Analytical RGA3 chromatograph with mercury vapour detector, with a precision of 5 ppbv $\mathrm{CO}$, calibrated with Air Liquide compressed cylinders, certified against the gravimetric scale

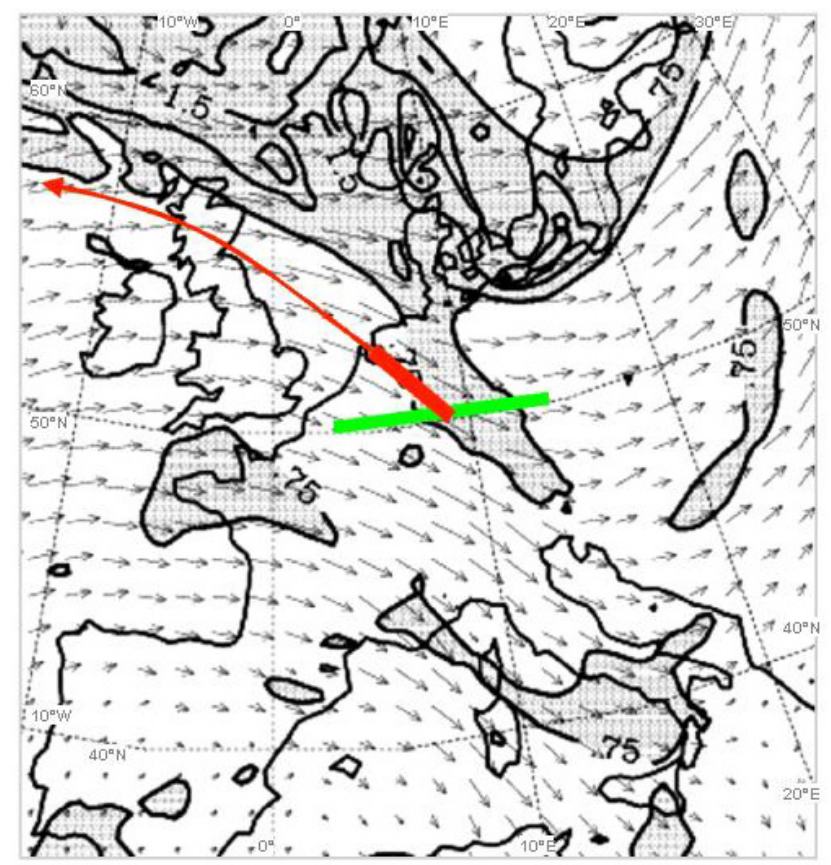

Fig. 8. Potential vorticity (contours every $0.75 \mathrm{pvu}$ ) and wind vectors on the $296 \mathrm{~K}$ isentropic surface on 10 February 2002, 12:00 UTC from ECMWF analyses. Horizontal line of the vertical cross-section shown on Fig. 9 is displayed in green about $50^{\circ} \mathrm{N}$. Flight track is displayed in red, larger for the ascent.

from NOAA/CMDL. Twelve air samples were analysed by laboratory GC at different altitudes between 300 and $5700 \mathrm{~m}$. The agreement with the MOZAIC CO analyser is good, particularly as the humidity variations found during this flight were large ( 0.5 to $\left.8 \mathrm{gH}_{2} \mathrm{O} / \mathrm{kgAir}\right)$.

The second comparison flight was undertaken on 7 July 2001, during the ESCOMPTE campaign (Cros et al., 2003). It was a flight dedicated to comparing measurements made by different aircraft. The Fokker 27 equipped with the MOZAIC CO analyser was flown together with the Dornier 128 (Corsmeier et al., 2001) operated by the Institute of Meteorology and Climate Research, Forschungszentrum Karlsruhe (Germany). This aircraft was equipped with an Aerolaser AL5001 vacuum UV resonance fluorescence CO instrument (Gerbig et al., 1999). During nearly three hours of flight, the aircraft altitudes ranged between 150 and $3000 \mathrm{~m}$ altitude in the Marseille (France) area, with water vapour ranging from 4 to $9 \mathrm{~g} \mathrm{H}_{2} \mathrm{O} / \mathrm{kgAir}$. No large pollution plumes were encountered (stable 10 knots north-west wind), $\mathrm{CO}$ values ranging from 100 to $140 \mathrm{ppbv}$. However, two small pollution plumes of $140 \mathrm{ppbv} \mathrm{CO}$ were observed, one being seen by both instruments (lasting $30 \mathrm{~s}, 1 \mathrm{~km}$ ), the second one (lasting $15 \mathrm{~s}, 0.5 \mathrm{~km}$ ) was only observed by the fast response Aerolaser instrument. This event is circled in red on Fig. 4 and reflects the limitation of the IR instrument in term of sensitivity and response time, compared to the resonance 


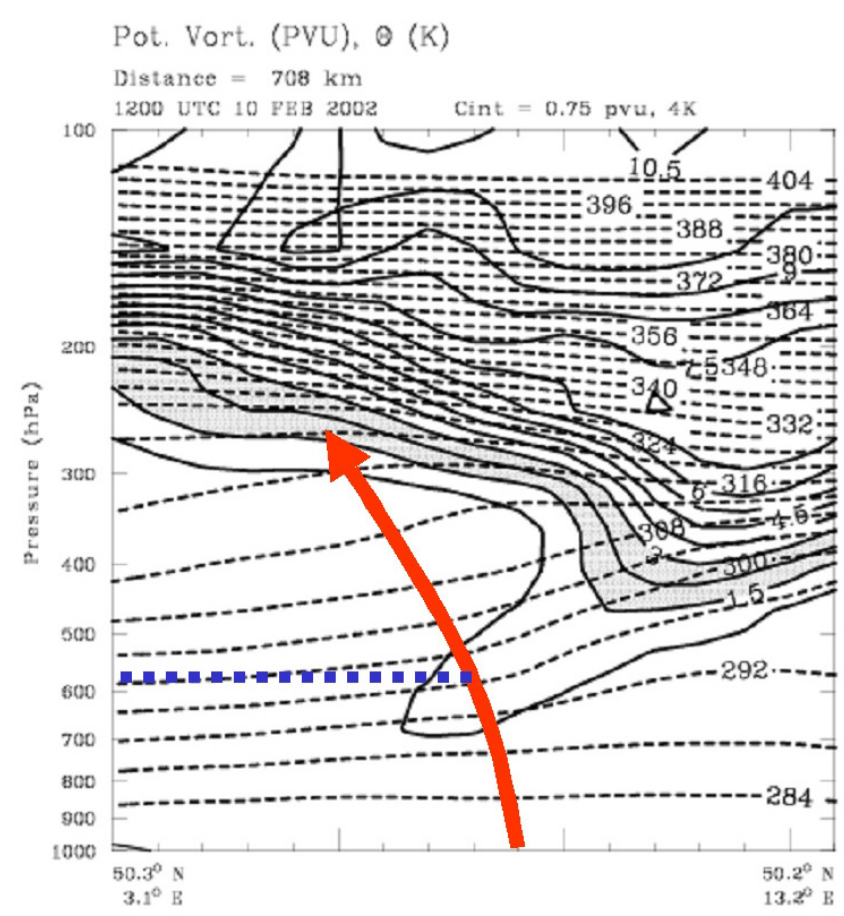

Fig. 9. Vertical cross section of potential vorticity (solid contours, every $0.75 \mathrm{pvu}$, shaded between 1.5 and $3.0 \mathrm{pvu}$ ) and potential temperature (dashed lines, every $4 \mathrm{~K}$ ) on 10 February 2002, 12:00 UTC. The line of cross section goes from $50.3^{\circ} \mathrm{N}-3.1^{\circ} \mathrm{E}$ to $50.2^{\circ} \mathrm{N}-$ $13.2^{\circ} \mathrm{E}$, the ascent from Frankfurt is displayed in red. The pressure altitude of the ozone maximum is the blue dashed line.

fluorescence instrument. The lower regression coefficient of 0.92 of the Dornier instrument may be caused by the different response times of the compared instruments.

The third comparison was performed on 2 and 3 October 2002, during the CAATERII campaign. The MOZAIC $\mathrm{CO}$ analyser was installed in the DLR operated Falcon 20. The first flight was between Oberpfaffenhofen (Germany), Orléans (France), Paderborne (Germany), the second flight was from Paderborne to Balaton (Hungary) and the final flight was between Balaton and Salzburg (Austria). The flights were mainly below $1000 \mathrm{~m}$ altitude, with profiles up to $5000 \mathrm{~m}$ altitude. Flask samples were made by LSCE and subsequent analysis by gas chromatography as for the RAMCES programme (see previous text).

The Falcon flights occurred mainly in the central European boundary layer and sampled higher $\mathrm{CO}$ concentrations (150-270 ppbv) than those described earlier by the Merlin and Fokker flights performed in relatively clean air, the $\mathrm{CO}$ concentration ranging between 80 and $140 \mathrm{ppbv}$. Figure 4 presents the comparisons between the MOZAIC CO analyser, the resonance fluorescence instrument and the GC analysis for the flask samples during the two campaigns (Series1 for Merlin flights and Series2 for the three Falcon flights). For the flask samples comparison, MOZAIC CO data have been averaged over the time intervals in which the flask samples were filled.

The linear regressions and correlation factors calculated for the three inter-comparison (see Fig. 4) show the good agreement (slopes near unity) between the MOZAIC IR instrument (5 ppbv, 5\%) and the two other methods: resonance-fluorescence (5 ppbv, 2.5\%) and gas chromatography (5 ppbv, 2\%). For resonance-fluorescence and gas chromatography series 1 , the samples were done in a limited range between $75 \mathrm{ppbv}$ and $125 \mathrm{ppbv}$, resulting in a lower accuracy of the linear fit. But the calculations $(7+0.97 \mathrm{X}$ and $-11+1.08 \mathrm{X}$ respectively) fit roughly into the cumulative precisions of the methods ( $10 \mathrm{ppbv}, 7.5 \%$ and $10 \mathrm{ppbv}$, $7 \%$ ) respectively. For the gas chromatography series 2 , the samples range from 80 to $270 \mathrm{ppbv}$ and the linear fit is better $(-4+1.05 \mathrm{X})$ well within the cumulative precisions of the methods (10 ppbv, 7\%). These intercomparison under aircraft operational conditions clearly show that this new instrument is highly suitable for making measurements of $\mathrm{CO}$ in the atmosphere.

\subsubsection{Co-located MOZAIC aircraft}

As MOZAIC systems are installed on five commercial aircraft operating from Europe over long range routes, aircraft are roughly co-located a few times per month, both spatially and temporally. These events offer clear opportunities to inter-compare the measurements made by the different aircraft. This has been done systematically since 1994 for ozone (Marenco et al., 1998) and is now applied to the new $\mathrm{CO}$ measurements. Figure 5 presents the $\mathrm{CO}$ measurements made by two MOZAIC aircraft and shows good agreement between the two systems, within the measurement uncertainty ( \pm 5 ppbv $\mathrm{CO}, \pm 5 \%)$.

\section{First scientific results using new CO measurements}

To show the scientific usefulness of the new MOZAIC CO measurements 3 case studies are presented here which highlight different potential uses of these measurements.

\subsection{Vertical profiles}

The first case study is a typical example of a winter midlatitude tropopause fold observed during a take-off from Frankfurt. Figure 6 shows a 1-km deep layer at a height of $5000 \mathrm{~m}$ altitude which is defined by a maximum in the ozone mixing ratio (up to $95 \mathrm{ppbv}$ ), and minima in the carbon monoxide and water vapour mixing ratios (down to $112 \mathrm{ppbv}$ and $0.2 \mathrm{~g} / \mathrm{kg}$ respectively). Similar mixing ratio of $\mathrm{O}_{3}, \mathrm{CO}$, and $\mathrm{H}_{2} \mathrm{O}$ are not sampled elsewhere in the vertical profile until the aircraft enters the stratosphere at a height of $10 \mathrm{~km}$. Baroclinic signatures that further characterize the tropopause folding process from which this layer originates are the change in the temperature lapse rate and the strong 


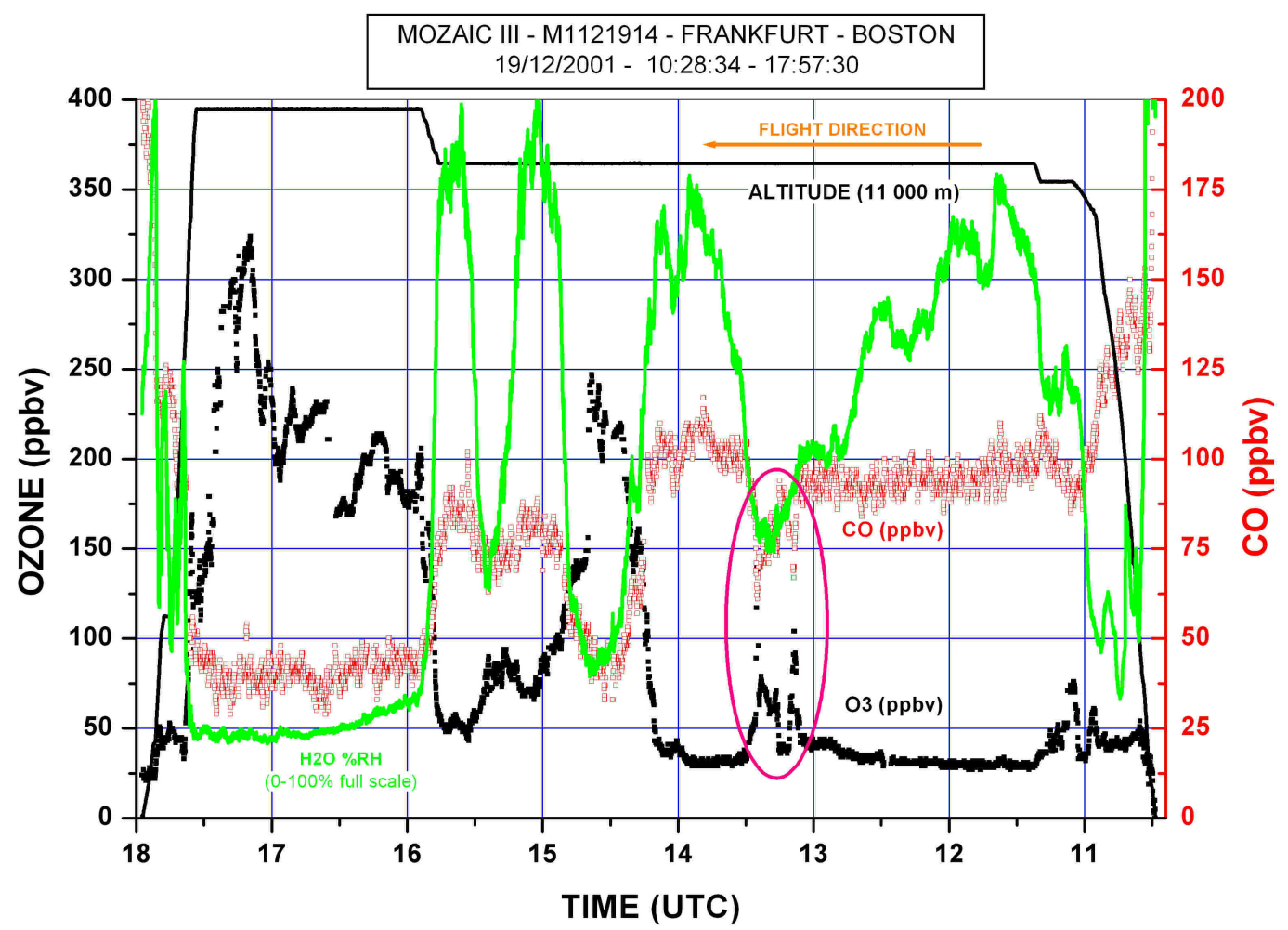

Fig. 10. Time series of MOZAIC parameters during a flight from Frankfurt to Boston on 19 December 2001 from 10:28 to 17:57 UTC: ozone mixing ratio (ppbv, black dots), carbon monoxide mixing ratio (ppbv, red line), relative humidity (\%, green line) and flight altitude with flight direction $(\mathrm{m}$, black line). The region of the stratospheric filament is indicated by the pink circle, a zoom on the time series of MOZAIC parameters in this region is displayed on Fig. 11.

vertical wind shear observed in this MOZAIC vertical profile (not shown). The relative variations of $\mathrm{O}_{3}$ and $\mathrm{CO}$ tracers inside the fold are closed to be self-consistent despite the difference of integration time between the $\mathrm{O}_{3}$ analyser $(4 \mathrm{~s})$ and the $\mathrm{CO}$ analyser ( $30 \mathrm{~s}$ ) leading to about $40 \mathrm{~m}$ and $300 \mathrm{~m}$ vertical resolution, respectively. The hypothesis that the mixing ratio of ozone and of carbon monoxide inside the fold result linearly from a mixing of stratospheric and tropospheric air gives $\mathrm{VMR}_{\text {fold }}=\left(\mathrm{VMR}_{\text {stra }}+(1-) \mathrm{VMR}_{\text {trop }}\right.$, where (is the percentage of stratospheric air inside the fold and VMR is a volume mixing ratio into either the tropopause fold (fold), or the stratosphere (stra), or the troposphere (trop). From Fig. 6, we have $\left(\mathrm{VMR}_{\mathrm{O}_{3}-\text { trop }}=50 \mathrm{ppbv} ; \mathrm{VMR}_{\mathrm{CO}-\text { trop }}=143 \mathrm{ppbv}\right)$ and $\left(\mathrm{VMR}_{\mathrm{O}_{3}-\text { fold }}=95 \mathrm{ppbv} ; \mathrm{VMR}_{\mathrm{CO}-\text { fold }}=117 \mathrm{ppbv}\right)$. According to Fig. 10, stratospheric air has about $\mathrm{VMR}_{\mathrm{CO}-\text { stra }}=37 \mathrm{ppbv}$ when $\mathrm{VMR}_{\mathrm{O}_{3}-\text { stra }}=320 \mathrm{ppbv}$. It agrees with a statistical analysis done with the whole MOZAIC dataset over winter 2002 indicating that the linear relationship between stratospheric $\mathrm{O}_{3}$ and $\mathrm{CO}$ is described by $\left(\mathrm{VMR}_{\mathrm{CO}-\text { stra }}=-1 / 5\right.$ $\mathrm{VMR}_{\mathrm{O}_{3}-\text { stra }}+98 ; \mathrm{R}=-0.7$ ) where the belonging to the stratosphere comes from a threshold on the potential vorticity (PV $>2$ pvu, Hoskins et al., 1985) deduced from ECMWF analyses. It follows that $(=0.17$ or $(=0.24$ depending on whether the relationship on volume mixing ratio is solved for $\mathrm{O}_{3}$ or for $\mathrm{CO}$, respectively. About $20 \%$ of the air inside the fold comes from the stratosphere. Using $(=0.17$ for $\mathrm{CO}$ gives $\mathrm{VMR}_{\mathrm{CO}-\text { fold }}=125 \mathrm{ppbv}$, which in comparison with the observation represents a difference of about $7 \%$ still closed to the instrument's accuracy. Therefore, the difference of integration time between the two MOZAIC analysers does not seem to prevent fine scale interpretations that are needed for the validation of present mesoscale numerical models studying the budget of trace gases in the planetary boundary layer and in the free troposphere.

A synoptic study of the meteorological situation, performed using ECMWF analyses, highlights the existence of a tropopause fold over Frankfurt on that day. An upper-level trough moved over Frankfurt (Fig. 7) which is situated just west of the vertical tropopause break on the cyclonic-shear side of the polar jet-stream. Upper-level frontogenesis has developed a stratospheric intrusion whose horizontal extension on the 296-K isentropic surface (Fig. 8) draws a tongue of relatively high potential vorticity (exceeding $0.75 \mathrm{pvu}$ ) stretching along the vertical tropopause break in the region of Frankfurt. In the vertical plane across the polar jet stream and Frankfurt (Fig. 9), the tropopause fold appears like a typical stratospheric intrusion with potential vorticity isocontours slanting along isentropic surfaces. The vertical profile 


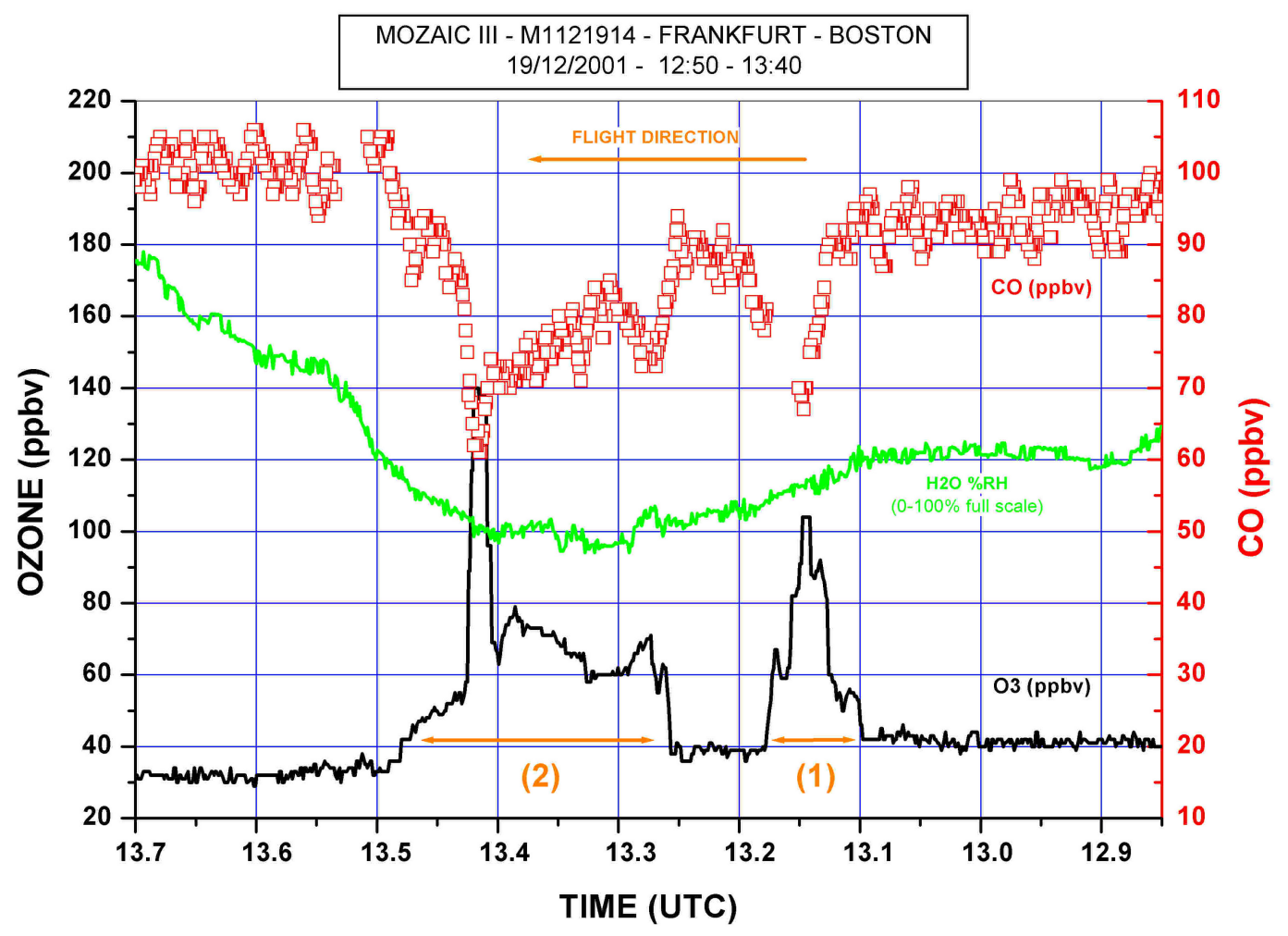

Fig. 11. Time series of MOZAIC parameters during a flight from Frankfurt to Boston on 19 December 2001 from 12:50 to 13:40 UTC: ozone mixing ratio (ppbv, black dots), carbon monoxide mixing ratio (ppbv, red line), relative humidity (\%, green line) and flight direction arrow (orange). Stratospheric episodes discussed in the text are labelled (1) and (2).

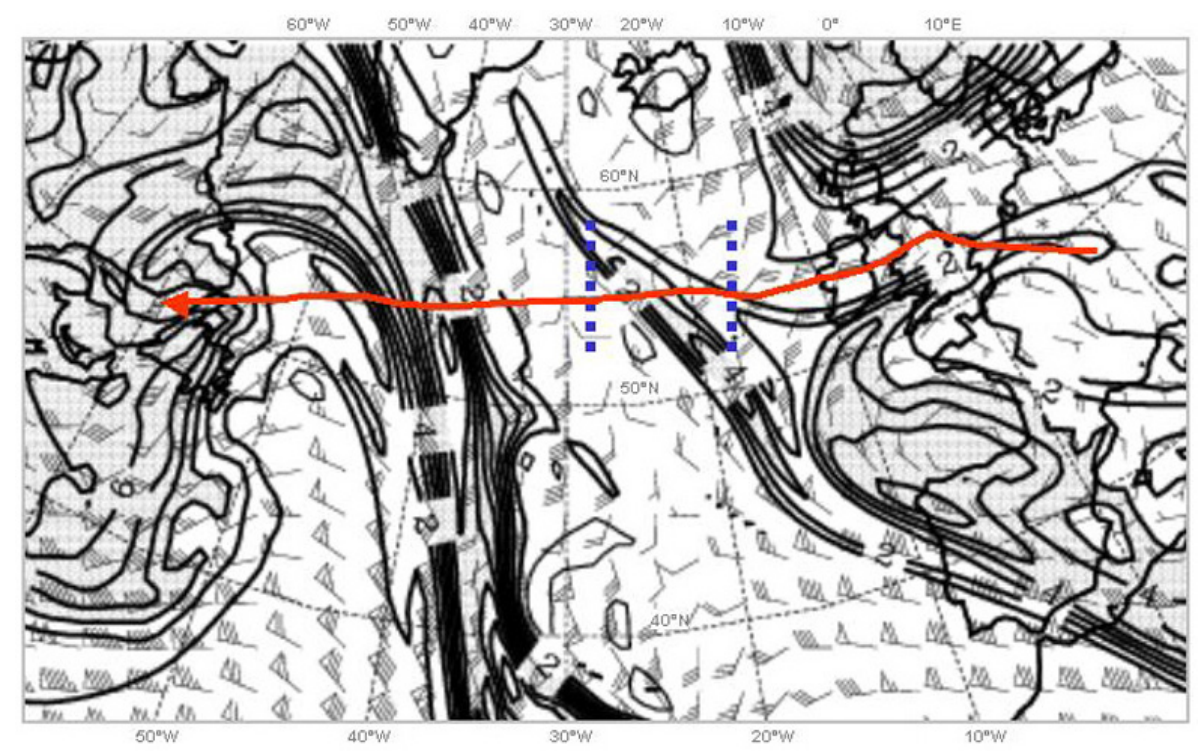

Fig. 12. Potential vorticity (contours every $1 \mathrm{pvu}$, shaded for values in excess of $3 \mathrm{pvu}$ ) at $250 \mathrm{hPa}$ (near the flight level, $\cong 227 \mathrm{hPa}$ ) on 19 December 2001, 12:00 UTC from ECMWF analyses. The red horizontal line near $55^{\circ} \mathrm{N}$ represents the flight path, the vertical lines in dashed blue highlights the period 12:50 to 13:40 UTC. 


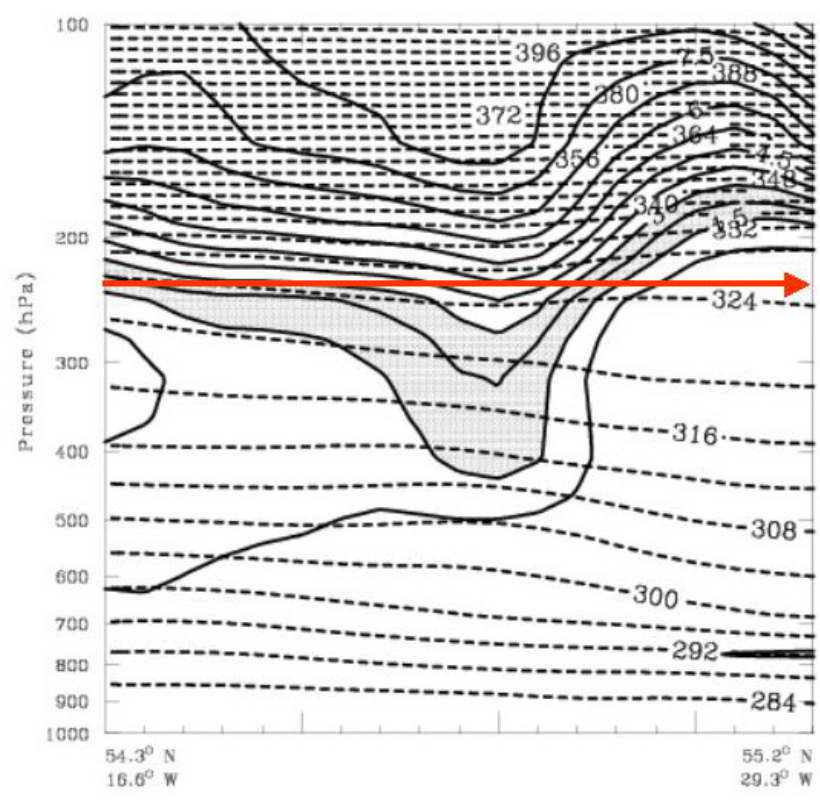

Fig. 13. Vertical cross section of potential vorticity (solid lines, every $0.75 \mathrm{pvu}$, shaded for values between 1.5 and $3.0 \mathrm{pvu}$ ) and potential temperature (dashed contour lines, every $4 \mathrm{~K}$ ) on 19 December 2001 12:00 UTC, over $818 \mathrm{~km}$. The cross section goes from $54.3^{\circ} \mathrm{N}-18.6^{\circ} \mathrm{W}$ to $55.2^{\circ} \mathrm{N}-29.3^{\circ} \mathrm{W}$ along the aircraft path over the Atlantic, it corresponds to the period from 1249 UTC to 13:46 UTC on Fig. 12 (see $\mathrm{O}_{3}, \mathrm{CO}$, and $\mathrm{H}_{2} \mathrm{O}$ time series). The red arrow represents the aircraft pressure altitude along the flight.

performed by the aircraft (Fig. 6) occurs approximately in the middle of the vertical cross-section of the stratospheric intrusion (Fig. 9).

\subsection{UTLS studies}

The second case study concerns a stratospheric filament sampled over the Atlantic during the cruise phase of the very first MOZAIC-III flight performed with $\mathrm{O}_{3}, \mathrm{H}_{2} \mathrm{O}$ and $\mathrm{CO}$ analysers on 19 December 2001. Figure 10 shows that the aircraft flying in both the troposphere, typified by low mixing ratios of $\mathrm{O}_{3}$, high mixing ratios of $\mathrm{CO}$, and relatively high values of humidity (for example between 11:24 and 12:49 UTC), and within the stratosphere typified by high mixing ratios of $\mathrm{O}_{3}$, low mixing ratios of $\mathrm{CO}$, and low relative humidity (for example between 15:52 and 17:31 UTC for instance). An zoomed-in view of the MOZAIC measurements during a period of strong $\mathrm{O}_{3}$ gradients is displayed in Fig. 11. Compared to the upper tropospheric background values of $\mathrm{O}_{3}(30-40 \mathrm{ppbv})$ and $\mathrm{CO}(90-100 \mathrm{ppbv})$, two air masses of stratospheric-origin can be defined by the simultaneous increase of $\mathrm{O}_{3}$ concentration and decrease of $\mathrm{CO}$ concentration. Labelled (1) and (2) in Fig. 11, they have length of $77 \mathrm{~km}$ and $220 \mathrm{~km}$ respectively, and are separated by a tropospheric episode of about $70 \mathrm{~km}$ length (from 13:10 to 13:15 UTC). The two ozone "cores" $\left(\mathrm{O}_{3}\right.$ in excess of about $80 \mathrm{ppbv}$ ) have lengths of about $20-30 \mathrm{~km}$ and are sampled with $1 \mathrm{~km}$ horizontal resolution $\left(4 \mathrm{~s}\right.$ at $250 \mathrm{~ms}^{-1}$ cruise speed). The $\mathrm{CO}$ horizontal resolution ( $\sim 7 \mathrm{~km}$ at cruise level) is still enough good to get several independent samples in the ozone cores so that the $\mathrm{CO}$ signatures are significant. However, the time response of the water vapour sensor at cruise altitude is several minutes (Helten et al., 1998) which does not allow the structure seen in $\mathrm{O}_{3}$ and $\mathrm{CO}$ to be captured.

A synoptic study of the meteorological situation, again performed with ECMWF analyses, shows that the aircraft flew through a stratospheric filament stretching from the midAtlantic south of Greenland to Portugal (Fig. 12). The vertical cross-section (Fig. 13) along the aircraft path (delimited by the start and end points of the time series shown on Fig. 11) confirms the local breakdown of the height of the tropopause. Nevertheless, neither the isobaric distribution of potential vorticity near the aircraft flight level nor the vertical cross-section of potential vorticity along the aircraft path reproduces the internal mesoscale structure of the filament as shown by MOZAIC in-situ data. The information content of MOZAIC data on mesoscale atmospheric structures is high compared to up-to-date numerical analyses and thus appropriate for mesoscale numerical models.

\subsection{Tropical studies}

Whereas the magnitude of $\mathrm{CO}$ sources over Europe and North America (due to energy production, transport etc.) are believed to be well constrained, emissions of $\mathrm{CO}$ from lessdeveloped and typically tropical regions (due to two-stroke engines, biomass burning, small scale coal combustion etc.) are much less well understood. Understanding the magnitude of the emissions from these less developed regions in important in understanding the past, present and future concentrations of CO in the atmosphere (Dickerson et al., 2002). MOZAIC flights in tropical regions are therefore particularly appropriated to study the composition of the atmosphere for which budgets of $\mathrm{O}_{3}$ and $\mathrm{CO}$ are of interest. Furthermore, as these commercial aircraft perform round trip flights, landing and take-off flight gives a way to document the time evolution of the vertical profile over a given place. For example MOZAIC flights to India (Frankfurt-Mumbai-Frankfurt), or Africa (Frankfurt-Lagos-Accra-Lagos-Frankfurt) provide 2 (Mumbai) or 4 (Lagos) vertical profiles of the planetary boundary layer within a few hours of each other. As an illustration of the potential of MOZAIC data over the tropics, the third case study highlights the composition of the planetary boundary layer over Mumbai during the dry season. On 24 February 2002, a descent over Mumbai at approximately 18:00 UTC (not shown) is followed by an ascent at around 21:30 UTC (Fig. 14).

The top of the planetary boundary layer is defined by the sharp decrease of water vapour, ozone and carbon monoxide mixing ratios at an altitude of $2500 \mathrm{~m}$. The polluted planetary 


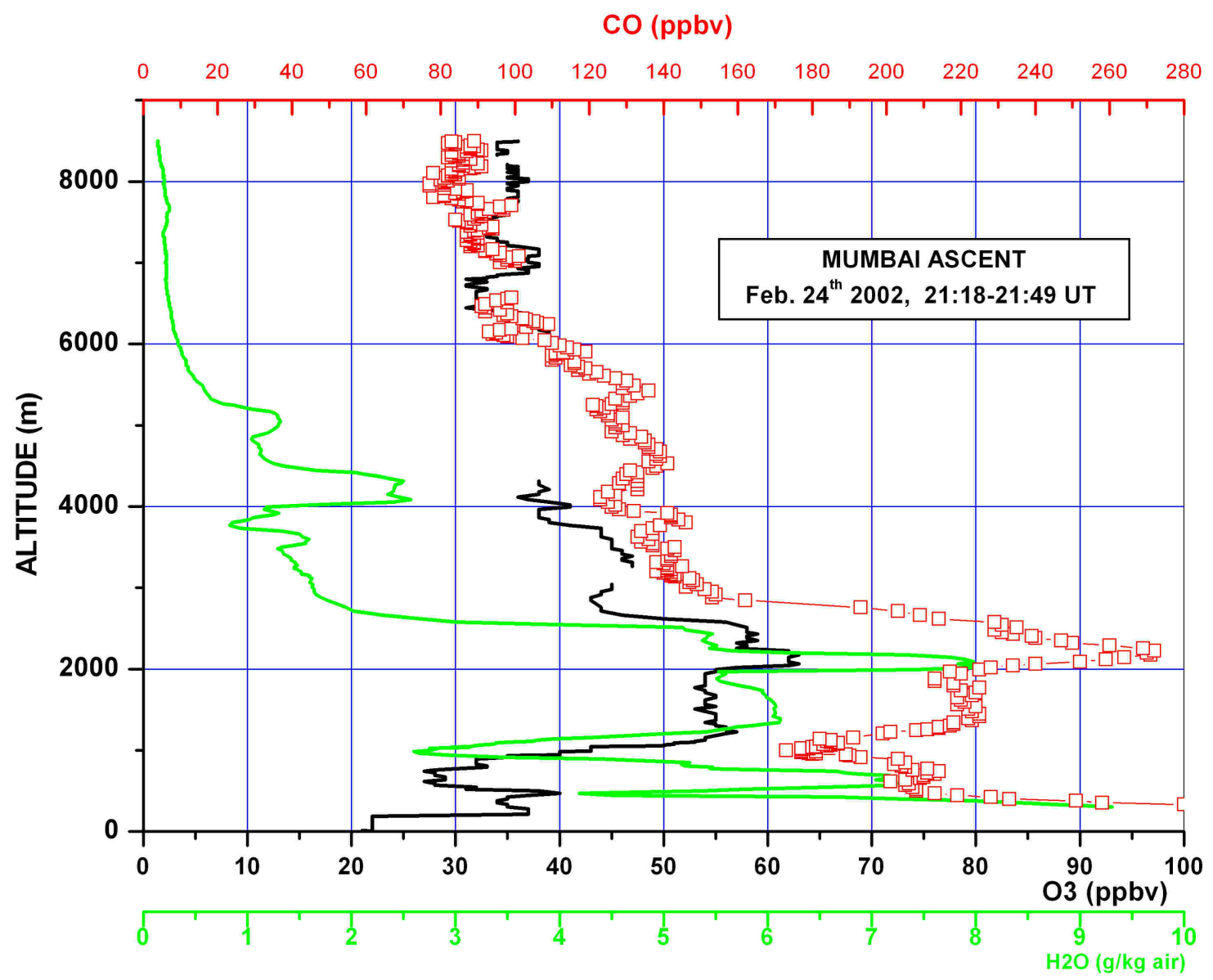

Fig. 14. Vertical profile over Mumbai (India) on 24 February 2002 from 21:18 to 21:49 UTC. Mixing ratio of ozone (ppbv, black solid line), carbon monoxide (ppbv, red square line) and water vapour ( $\mathrm{g} / \mathrm{kg}$, green line) versus altitude $(\mathrm{m})$.

boundary layer is laden with $\mathrm{O}_{3}$ and $\mathrm{CO}$. A further examination of tracer variations leads to the identification of three layers within the boundary layer. The first is below the top of the planetary boundary layer at $2000 \mathrm{~m}$ altitude which is characterized by a maximum in both $\mathrm{H}_{2} \mathrm{O}, \mathrm{O}_{3}$, and $\mathrm{CO}$ mixing ratio, the second is at an altitude around $1000 \mathrm{~m}$ which is rather dry, has a relative minimum in $\mathrm{CO}$ mixing ratio and a strong vertical gradient of $\mathrm{O}_{3}$, and the third layer is located below $500 \mathrm{~m}$ and is characterized by high values of relative humidity and $\mathrm{CO}$ and shows the signature of the dry deposition process of $\mathrm{O}_{3}$ to the surface.

\section{Conclusions}

MOZAIC is a unique programme which provides regular sampling of the UTLS region and performs vertical profiles over a variety of different locations across the globe (with the notable except of the Pacific, up to now). The routinelyoperated CO analysers developed and flown for the MOZAIC programme will provide an extensive data base over several years for carbon monoxide, as already been provided for ozone and water vapour since 1994. On one aircraft, additional $\mathrm{NO}_{\mathrm{y}}$ measurements (Volz-Thomas from FZ Jülich, Germany) complement the suite of measurements. From December 2001 to May 2003, more than 1300 long range flights have been obtained with simultaneous $\mathrm{O}_{3}, \mathrm{CO}$ and $\mathrm{H}_{2} \mathrm{O}$ measurements (nearly 10000 flight hours).

The first year of operation of the routine MOZAIC CO analyser have shown the MOZAIC CO analyser's reliability in the difficult operational conditions of commercial aircraft. The instrument performance ( $\pm 5 \mathrm{ppbv} \mathrm{CO}, \pm 5 \%)$ is suitable for atmospheric studies, no interferences have been seen and in-flight comparisons with other measurement techniques have been positive. Future developments are planned for this method, including an improvement of the sensitivity/response time by use of a new generation IR detectors and the weight reduction of the entire MOZAIC systems by integration of the $\mathrm{O}_{3}$ and $\mathrm{CO}$ instruments with a single acquisition computer.

Acknowledgements. The MOZAIC programme is supported by the European Commission (EVK2-CT1999-00015). We express our gratitude to Lufthansa, Air France, Austrian Airlines and Sabena 
which have carried the MOZAIC systems free of charge since 1994. Many thanks go to the organisations which made possible the different flight tests of the instruments: Airbus on A340 MSN001, Centre d'Aviation Météorologique of Météo-France on Merlin IV, Institut National des Sciences de l'Univers et de l'Environnement from CNRS on the Fokker 27 "ARAT" and Dassault Mystère 20. For the intercomparisons flights, many thanks go to Laboratoire des Sciences du Climat et de l'Environnement (CNRS-CEA) and to the Institute of Meteorology and Climate Research Forschungszentrum Karlsruhe for the Resonance-Fluorescence measurements on the Dornier 128.

\section{References}

Corsmeier, U., Hanker, R., and Wieser, A.: Airborne turbulence measurements in the lower troposphere onboard the research aircraft Dornier 128-6, D-IUBF, Meteorologische Zeitschrift, 10, 4, 315-329, August 2001.

Cros B., Durand, P., Frejafon, E., Kottmeier, C., Perros, P. E., Peuch, V.-H., Robin, D., Sad, F., Toupance, G., and Wortham, H.: The ESCOMPTE programme: An overview, accepted to Atmospheric Research, 2003.

Dickerson, R. R. and Delany, A. C.: Modification of a commercial gas filter correlation $\mathrm{CO}$ detector for enhanced sensitivity. J. Atmos. Oceanic Technol., 5, 424-431, 1987.

Dickerson, R. R., Andreae, M. O., Campsos, T., Mayol-Bracero, O. L., Neusuess, C., and Streets, D. G.: Analysis of black carbon and carbon monoxide observed over the Indian Ocean: Implications for emissions and photochemistry. J. Geophys. Res, 107, 8017, doi:10.1029/2001JD000501, 2002.

Fried, A., Henry, B., Parrish, D. D., Carpenter, J. R., and Buhr, M. P.: Intercomparison of tunable diode laser and gas filter correlation measurements of ambient carbon monoxide, Atmos. Environ.,25A, 2277-2284, 1991.

Edwards, D., Lamarque, J.-F., Attié, J.-L., Emmons, L. K., Richter, A., Cammas, J.-P., Lyjak, L. V., Francis, G. L., Gille, J. C., and Drummond, J. R.: Tropospheric ozone over the tropical Atlantic: A satellite perspective, J. Geophys. Res., accepted, 2003.

Emmons, L. K., Hauglustaine, D. A., Muller, J.-F., Caroll, M. A., Brasseur, G. P., Brunner, D., Staehelin, J., Thouret, V. and Marenco, A.: Data composites of airborne observations of tropospheric ozone and its precursors. J. Geophys. Res. 105, $20497-$ 20 538, 2000.

Gerbig. C., Smitgen, S., Kley, D., Volz-Thomas, A., Dewey, H., and Haaks, D.: An improved fast response vacuum UV resonance fluorescence CO instrument, J. Geophys. Res., 104, 1699-1704, 1999.

Gerbig, C., Kley, D., Volz-Thomas, A., Kent, J., Dewey, K., and McKenna, D. S.: Fast response resonance fluorescence CO measurements aboard the C-130: Instrument characterisation and measurements made during North Atlantic Regional Experiment 1993, J. Geophys. Res., 101, 29 229-29 238, 1996.

Gros, V., Sarda-Esteve, R., Bonsang, B., Ramonet, M., and Valant, C.: Mesure du monoxyde de carbone par chromatographie en phase gazeuse - DSM-LSCE, CEA-R-5814, CEA Saclay, 1998.

Helten, M., Smit, H. G. J., Sträter, W., Kley, D., Nedelec, P., Zöger, M., and Busen, R.: Calibration and performance of automatic compact instrumentation for the measurement of relative humidity from passenger aircraft, J. Geophys. Res., 103, 25643 $25652,1998$.

Hoel, J. M., Jr., Gregory, G. L., McDougal, D. S., Sachse, G. W., Hill, G. F., Condon, E. P., and Rasmussen, R. A.: Airborne intercomparison of carbon monoxide measurement techniques, J. Geophys. Res., 92, 2009-2019, 1987.

Hoskins, B. J., Mc Intyre, M. E., and Robertson, A. W.: On the use and significance of isentropic potential vorticity maps, Quart. Journal of the Royal Met. Soc., 111, 877-946, 1985.

Logan, J. A., Prather, M. J., Wofsy, S. C., and McElroy, M. B.: Tropospheric chemistry : A global perspective, J. Geophys. Res., 86, 7210-7254, 1981.

Marenco, A., Thouret, V., Nédélec, P., Smit, H. G. J., Helten, M., Kley, D., Karcher, F., Simon, P., Law, K., Pyle, J., Poschmann, G., von Wrede, R., Hume, C., and Cook, T.: Measurement of ozone and water vapour by Airbus in-service aircraft: The MOZAIC airborne programme, An overview, J. Geophys. Res., 103, 25 631-25 642, 1998.

Marenco, A., Macaigne, M., and Prieur, S.: Meridional and vertical $\mathrm{CO}$ and $\mathrm{CH}_{4}$ distributions in the background troposphere $\left(70^{\circ} \mathrm{N}-60^{\circ} \mathrm{S} ; 0-12 \mathrm{~km}\right.$ altitude) from scientific aircraft measurements during the STRATOZ III experiment, Atmos. Environ., 23, 185-200, 1989.

Matsueda, H., Inoue, Y., Sawa, Y., Tsutsumi, Y., and Ishii, M.: Carbon monoxide in the upper troposphere over the western Pacific between 1993 and 1996, J. Geophys. Res., 103, 19093-19110, 1998.

Matsueda, H., Inoue, H. Y., Sawa, Y., Tsutsumi, Y., and Ishii, M.: Carbon monoxide in the upper troposphere over the western Pacific between 1993 and 1996. J. Geophys. Res., 103, 19093 $19110,1998$.

Matsueda, H. and Inoue, H. Y.: Aircraft measurements of trace gases between Japan and Singapore in October 1993, 1996, and 1997, J. Geophys. Res., 26, 2413-2416, 1999.

Novelli, P., Masarie, K. A., and Lang, P. M.: Distributions and recent changes of carbon monoxide in the lower tropsphere, J. Geophys. Res. 103, 19015-19033, 1998.

Parrish, D. D., Holloway, J. S., and Fehsenfeld, F. C.: Routine, continuous measurement of carbon monoxide with parts per billion precision. Environ. Sci. Tecnol., 28, 1615-1618, 1994.

Reichle, H. G., Connors, V. S., Holland, J. A., Hypes, W. D., Wallio, H. A., Casas, J. C., Gormsen, B. B., Saylor, M. S., and Hesketh, W. D.: Middle and upper tropospheric carbon monoxide mixing ratios as measured by a satellite-borne remote sensor during November 1981, J. Geophys. Res., 91, 10 865-10 887, 1986.

Reichle, H. G., Connors, V. S., Holland, J. A., Sherrill, R. T., Wallio, H. A., Casas, J. C., Condon, E. P., Gormsen, B. B., and Seiler, W.: The distribution of middle tropospheric carbon monoxide during early October 1984, J. Geophys. Res., 95, 9845-9856, 1990.

Reichle Jr., H. G., Anderson, B. E., Connors, V. S., Denkins, T. C., Forbes, D. A., Gormsen, B. B., Langenfelds, R. L., Neil, D. O., Nolf, S. R., Novelli, P. C., Pougatchev, N. S., Roell, M. M., Steele, L. P.: Space shuttle based global CO measurements during April and October 1994, MAPS instrument, data reduction, and data validation, J. Geophys. Res. 104, 21 443-21 454, 1999.

Sachse, G. W., Hill, G. F., Wade, L. O., and Perry, M. G.: Fastresponse, high-precision carbon monoxide sensor using a tunable diode laser absorption technique, J. Geophys. Res., 92, 20712081, 1987. 
Sachse, G. W., Collins, J. E., Jr., Hill, G. F., Wade, L. O., Burney, L. G., and Ritter, J. A.: Airborne tunable diode laser sensor for high precision concentration and flux measurements of carbon monoxide and methane, SPIE Proceedings, 1991.

Takegawa, N., Kita, K., Kondo, Y., Matsumi, Y., Parrish, D. D., Holloway, J. S., Koite, M., Miyazaki, Y., Toriyama, N., Kawakami, S., and Ogawa, T.: Airborne vacuum ultraviolet resonance fluorescence instrument for in situ measurement of $\mathrm{CO}$, J. Geophys. Res., 106, NO. D20, 24 237-24 244, 2001.
Thompson, A. M. and Ciccerone, R. J.: Posssible perturbations of atmospheric $\mathrm{CO}, \mathrm{CH}_{4}$ and $\mathrm{OH}$, J. Geophys. Res., 91, $10853-$ $10864,1986$.

Volz, A. and Kley, D.: A Resonance-Fluorescence Instrument for the In-Situ Measurement of Atmospheric Carbon Monoxide. J. Atmos. Chem., 2, 345-357, 1985. 